\title{
CASE REPORT: REMOVAL OF A PROLIFERATING PILOMATRICOMA WITH A $\mathrm{CO}_{2}$ LASER
}

Gaydina TA $\square$, Dvornikov AS, Skripkina PA

Pirogov Russian National Research Medical University, Moscow, Russia

Tumors of the skin/skin adnexa are astonishingly diverse. The diagnostic algorithms for skin neoplasms includes history taking, the assessment of clinical data, dermoscopy and a histopathological examination. Literature descriptions of a histologically confirmed pilomatricoma are scarce. If the lesion is localized to an esthetically sensitive body area, it is important to minimize the postoperative cosmetic defect. In the case described below, we were able to achieve a positive esthetic outcome in a patient with a facial pilomatricoma sized $<2 \mathrm{~cm}$ using a $\mathrm{CO}_{2}$ laser.

Keywords: pilomatricoma, benign skin tumor, removal, $\mathrm{CO}_{2}$ laser, diagnostic methods for skin neoplasms, artificial intelligence

Author contribution: Gaydina TA — surgery; literature analysis; data acquisition, analysis and interpretation; manuscript preparation; Dvornikov AS — literature analysis; data acquisition, analysis and interpretation; Skripkina PA — manuscript preparation.

Compliance with ethical standards: the patient gave informed consent to the surgical intervention and publication of her personal data.

$\triangle$ Correspondence should be addressed: Tatiana A. Gaydina

Ostrovityanova, 1, Moscow, 117997; doc429@yandex.ru

Received: 14.11.2019 Accepted: 21.11.2019 Published online: 01.12.2019

DOI: $10.24075 /$ brsmu.2019.077

\section{КЛИНИЧЕСКИЙ СЛУЧАЙ: УДАЛЕНИЕ ПРОЛИФЕРИРУЮЩЕЙ ПИЛОМАТРИКСОМЫ СО -ЛАЗЕРОМ}

\section{Т. А. Гайдина 凶, А. С. Дворников, П. А. Скрипкина}

Российский национальный исследовательский медицинский университет имени Н. И. Пирогова, Москва, Россия

В клинической практике врачи разных специальностей наблюдают большое разнообразие новообразований кожи (НК) и ее придатков. Алгоритм диагностики включает оценку анамнестических и клинических данных, дерматоскопическое и гистологическое исследования. Описание пиломатриксомы с гистологическим подтверждением диагноза представляет собой редкий клинический случай. При локализации пиломатриксомы на эстетически значимом участке кожного покрова задача врача минимизировать косметический десект после удаления. Мы получили положительный косметический результат после удаления пиломатриксомы диаметром менее $2 \mathrm{~cm}^{2}$ на коже лица методом $\mathrm{CO}_{2}$-лазерной деструкции.

Ключевые слова: пиломатриксома, доброкачественные новообразования кожи, удаление, СО искусственный интеллект

Информация о вкладе авторов: Т. А. Гайдина - проведение оперативного лечения, анализ литературы, сбор, анализ и интерпретация данных, подготовка черновика рукописи; А. С. Дворников - анализ литературы, сбор, анализ, интерпретация данных; П. А. Скрипкина - подготовка черновика рукописи.

Соблюдение этических стандартов: пациентка подписала добровольное информированное согласие на проведение оперативного лечения.

$\triangle$ Для корреспонденции: Татьяна Анатольевна Гайдина

ул. Островитянова, д. 1, г. Москва, 117997; doc429@уandex.ru

Статья получена: 14.11.2019 Статья принята к печати: 21.11.2019 Опубликована онлайн: 01.12.2019

DOI: $10.24075 /$ vrgmu.2019.077

The diversity of clinical presentations of skin neoplasms (SN) seen on physical examination and the ensuing difficulty in their differential diagnosis necessitate the use of additional diagnostic techniques. The initial examination of SN includes dermoscopy [1]; ultrasonography, siascopy, confocal laser scanning microscopy, [2] and near-infrared multispectral imaging [3] can also facilitate the diagnosis, if available. However, the application of these tools does not eliminate the possibility of misdiagnosis; even the findings of a histopathological examination, the gold standard of modern medicine, can be subject to misinterpretation [4]. Dermoscopy is a widespread technique for diagnosing melanocytic skin tumors in the first place [5]. Dermoscopy images of rare $\mathrm{SN}$, such as pilomatricoma, are underrepresented in the literature.

Pilomatricoma, also known as benign calcifying epithelioma, necrotizing epithelioma, calcifying epithelioma of Malherbe, and pilomatrixoma, is a rare benign skin neoplasm with follicular differentiation. In 1880, A. Malherbe and J. Chenantais hypothesized that the tumor derived from sebaceous glands [6]. In 1961, R. Forbis and E. Helwig coined the term "pilomatricoma" because they found that the tumor arose from the outer sheath cells of the hair follicle root [6]. F. Moehlenbeck reported that pilomatricoma accounted for $0.12 \%$ of 140,000 SN he had analyzed [6]. Today, it is known that pilomatricoma originates from the hair follicle matrix [7]. It is usually localized to the head or neck and is more often seen in children, especially girls, although adults are also affected [8]. Its clinical manifestations are diverse. The tumor can present as a small, barely noticeable subcutaneous lesion, as well as a bigger, more aggressive and locally invasive growth [9]. Due to its varying clinical presentations, pilomatricoma can be mistaken for a malignancy. Unattractive postoperative scars can cause emotional distress in patients with facial pilomatricomas. Therefore, the size and location of the lesion, the risk of developing a hypertrophic or keloid scar, comorbidities, and the patient's age should all be taken into account when deciding on the best treatment option. It is important to minimize the postoperative cosmetic defect and achieve an esthetically acceptable result.

\section{Clinical case}

Female patient $\mathrm{K}_{\text {., }}$ aged 52, presented with a skin lesion on her left cheek (Fig.1). She had first spotted the lesion 20 years before but never sought medical advice. The patient had tried to squeeze it on repeated occasions before she noticed the mass was growing.

Status localis: the patient's skin color was normal; her Fitzpatrick skin type was III. On the left cheek, there was 
a nodular pink-pale mass sized $10.0 \times 10.0 \times 0.5 \mathrm{~mm}$ with a heterogenous lobular structure and yellow inclusions. The mass was soft and non-tender on palpation. The surrounding skin was intact.

Dermoscopy allowed a 20x magnification. The examination revealed a mass with clear margins and a lobular structure, symmetrical on two axes; the mass had homogenous yellow and pale pink inclusions, tortuous blood vessels and skin flakes (Fig. 2).

The analysis of the dermoscopy image by a convolution neural network suggested a benign tumor.

Clinical diagnosis: a benign skin neoplasm of the face (D23.3).

Differential diagnosis: basal cell carcinoma, epidermoid cyst, atheroma, xanthogranuloma, dermal cylindroma, dermatofibroma.

Considering the location of the neoplasm and its size (up to $2 \mathrm{~cm}^{2}$ ), it was decided to remove it under local anesthesia using a $\mathrm{CO}_{2}$ laser; the procedure was preceded by a scalpel biopsy.

Histopathology: D17.0 Proliferating pilomatricoma (necrotizing epithelioma of Malherbe) (Fig. 3). ICD-O code: 8110/0.

The follow-up examination conducted 2 weeks after surgery revealed formation of a neat scar (Fig. 4, 5)

\section{Discussion}

Patients with SN seek medical advice from both cancer specialists and non-oncologists. According to the literature, skin malignancies are the most common cancer type reported in the Russian Federation, amounting to $12.6 \%$ (excluding melanoma) or $14.2 \%$ (including melanoma) [10]. It is critical that the patient should be immediately referred to an oncologist if clinical examination is suspicious of a skin/skin adnexa malignancy in order to make a timely diagnosis and decide on an adequate treatment strategy [11]. Pilomatricoma is a rare skin lesion, and physical examination alone does not provide the accurate diagnosis. In the case described in this article, we performed dermoscopy and carried out a histopathological study of the excised mass. With rare SN, there is always a risk that dermoscopy findings can be misinterpreted. In this regard, the use of artificial intelligence (Al) for the initial screening for $\mathrm{SN}$ is a promising approach [12]. At present, $\mathrm{Al}$ is employed to analyze digital microphotographs; it demonstrates high sensitivity in detecting malignancies. A convolutional neural network $(C N N)$ is trained on over 100,000 microphotographs

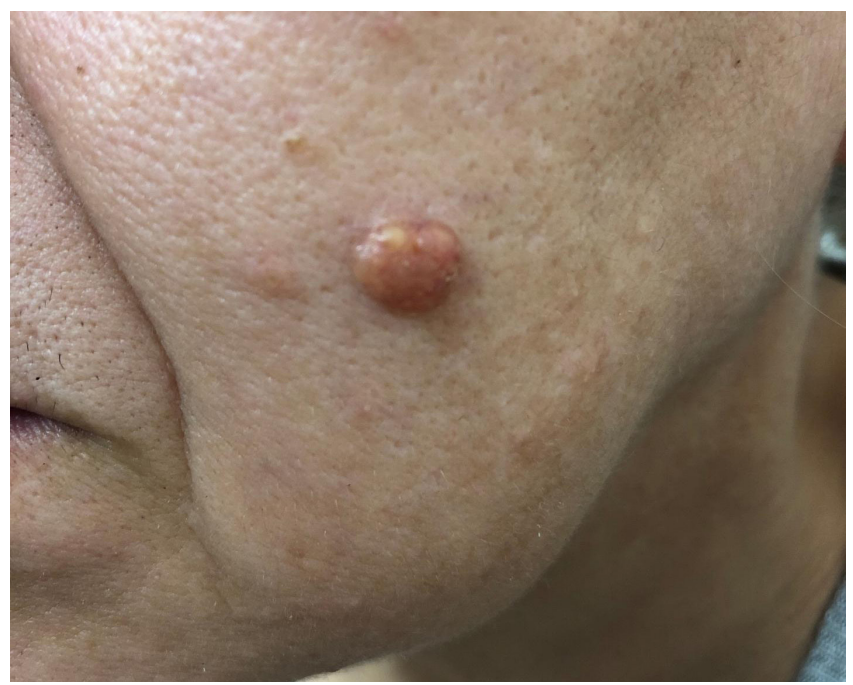

Fig. 1. A pale-pink skin nodule with yellow inclusions on the left cheek

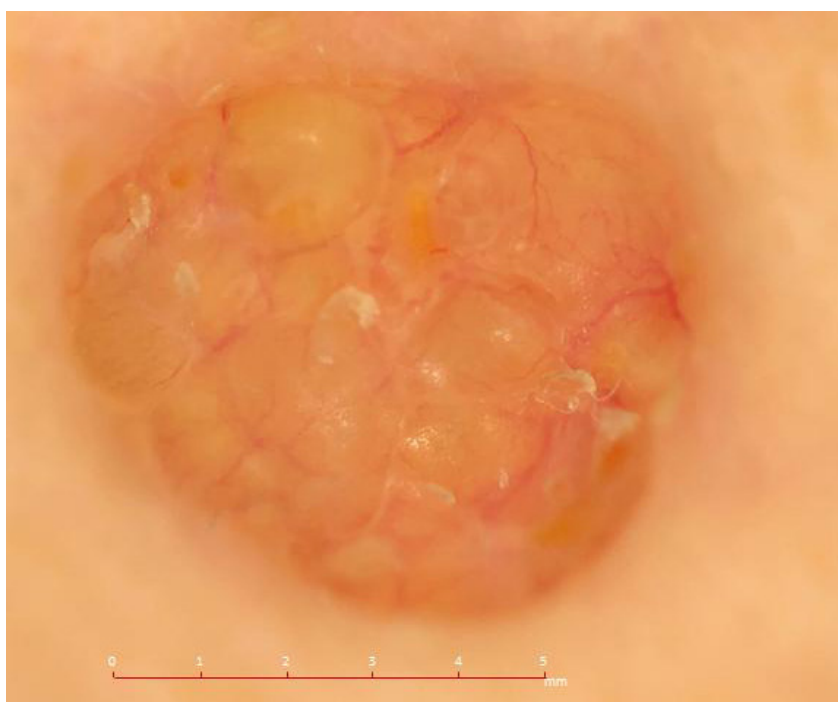

Fig. 2. Dermoscopy: a mass with a clear lobular structure, showing homogenous areas of yellow and pale pink, tortuous blood vessels and skin flakes (magnification: $\times 20$ )

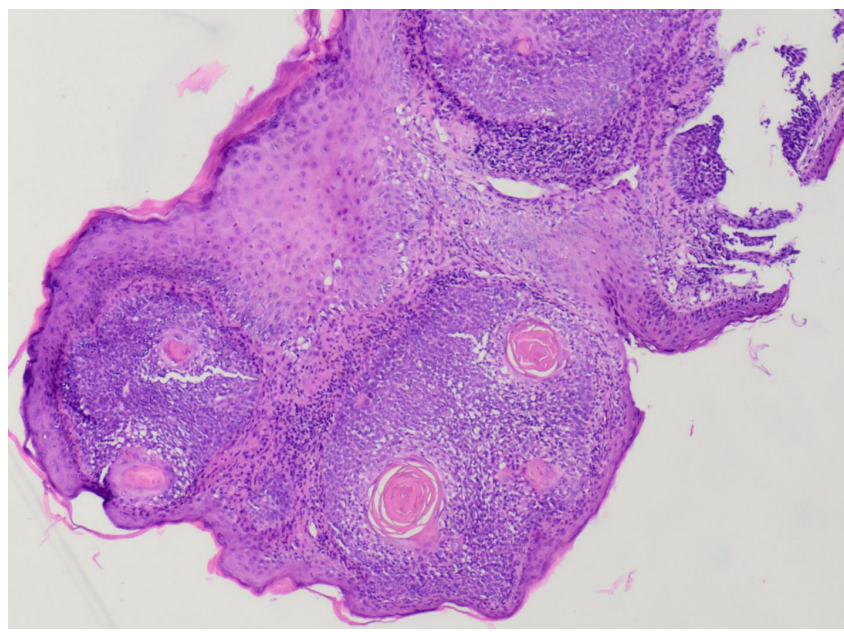

Fig. 3. A skin fragment with a nodule consisting of proliferating epithelial cells in a garland-resembling arrangement. Some of the cells are necrotic (the socalled shadow cells). Inflammatory cell infiltrate is seen around the layers of the epithelium (staining: hematoxylin and eosin; magnification $\times 40$ )

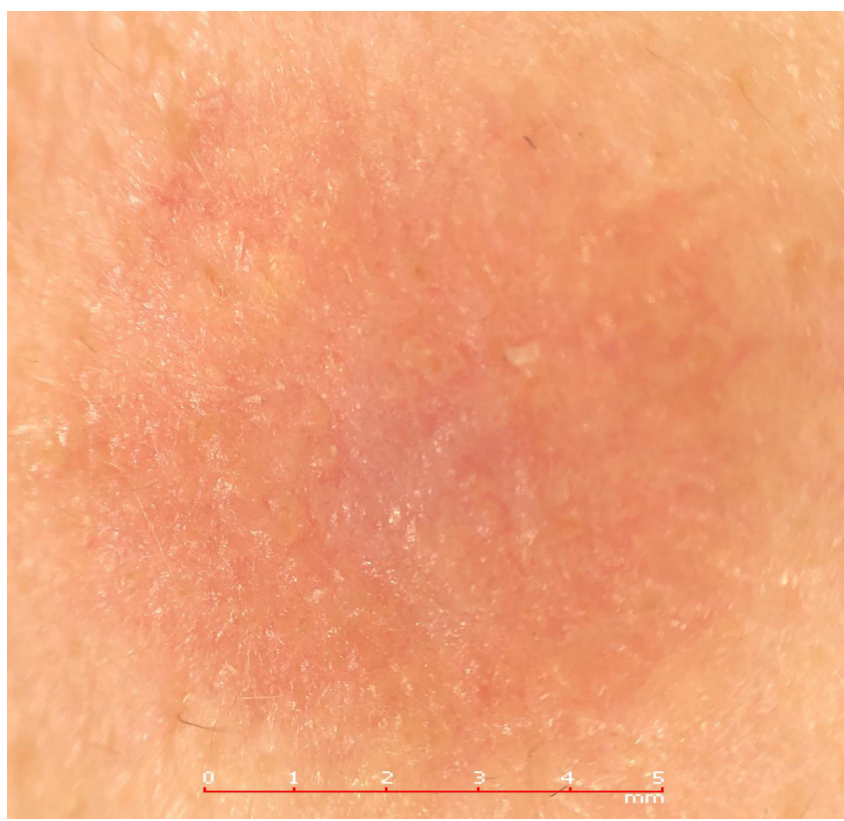

Fig. 4. Dermoscopy: a well-demarcated symmetrical pale pink area (magnification: $\times 20$ ) 
of $\mathrm{SN}$ with a histologically confirmed diagnosis [13]. It can build its own algorithms for decision making during the analysis. A trained CNN demonstrates better specificity and sensitivity in comparison with dermatologists who have little $(<2$ years) or moderate ( $>5$ years) experience in dermoscopy [13]. Of course, Al cannot replace humans in diagnosing $\mathrm{SN}$, but it can assist fledgling doctors in decision making. In the nearest future CNNs will continue to develop and will be trained on real clinical data; this will improve the diagnostic accuracy for such rare SN as pilomatricoma.

Due to the risk of postoperative hypertrophic scarring, facial surgery can be a stressful factor for the affected patients. The arsenal of techniques for pilomatricoma removal is broad and includes surgical excision, curettage, cauterization, cryosurgery, photodynamic therapy, and laser ablation. It is reported that the use of a $\mathrm{CO}_{2}$ laser for removing various $\mathrm{SN}$ and appendageal tumors of the face produces a good esthetic result $[14,15]$. A $\mathrm{CO}_{2}$ laser reduces the rate of pilomatricoma recurrence, the time needed for the surgical wound to epithelize, the incidence of intraoperative and postoperative complications, and increases the positive feedback rate. $\mathrm{A} \mathrm{CO}_{2}$ laser is highly effective in removing small $\left(<2 \mathrm{~cm}^{2}\right)$ pilomatricomas, providing a good esthetic result.

\section{CONCLUSIONS}

Physical examination alone is not enough to diagnose a pilomatricoma; additional noninvasive diagnostic tools should be employed. Dermoscopy is the most common technique in dermatology; however, the literature shows a lack of dermoscopy images of rare skin neoplasms, such as pilomatricoma. There is a need for a dermoscopy images database of rare skin tumors for the subsequent computer-assisted analysis in order to improve the accuracy of diagnostic screening. Pilomatricomas less than $2 \mathrm{~cm}^{2}$ in size, especially those located on esthetically sensitive body areas, should be removed using a $\mathrm{CO}_{2}$ laser. This technique produces a good esthetic result and minimizes cosmetic defects.

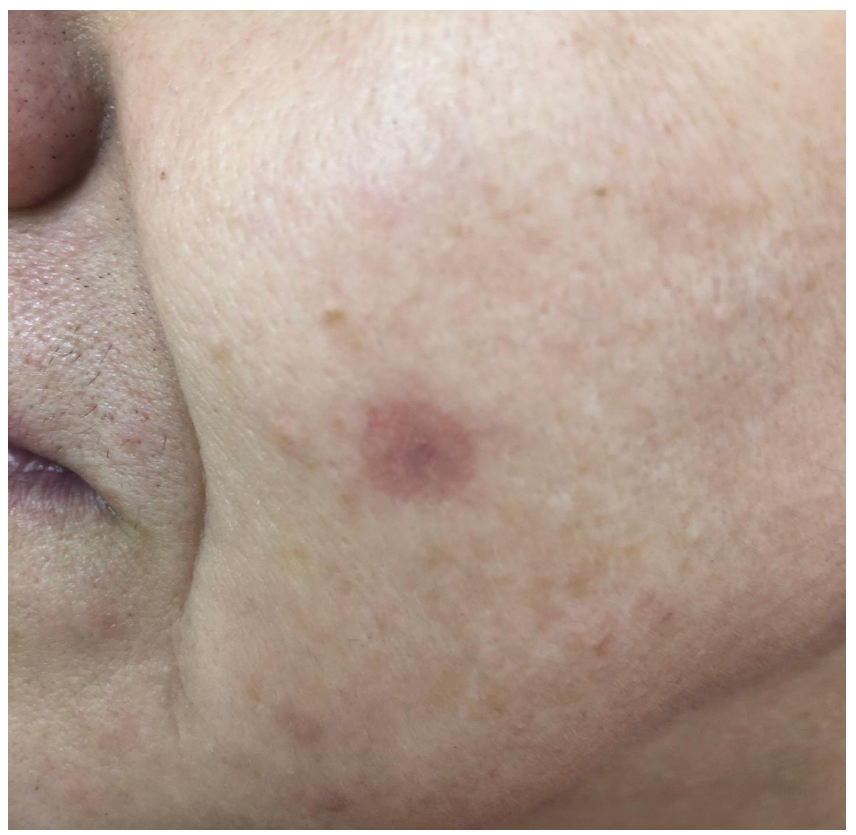

Fig. 5. A neat postoperative scar is staring to form

\section{References}

1. Kubanov AA, Sysoeva TA, Gallyamova YuA, Bisharova AS, Mercalova IB. Algoritm obsledovanija pacientov $s$ novoobrazovanijami kozhi. Lechashhij vrach. 2018; (3): 83-8. Russian.

2. Malishevskaya NP, Sokolova AV. Sovremennye metody neinvazivnoj diagnostiki melanomy kozhi. Vestnik dermatologii i venerologii. 2014; (4): 46-53. Russian.

3. Rey-Barroso L, Burgos-Fernández FJ, Delpueyo X, Ares M, Royo S, Malvehy, J, et al. Visible and Extended Near-Infrared Multispectral Imaging for Skin Cancer Diagnosis Sensors. 2018; 18 (5): 1441.

4. Kit Ol, Fomenko YuA, Karnauhov NS, Lapteva TO. Chastota rashozhdenija diagnoza $v$ prizhiznennoj patologoanatomicheskoj diagnostike onkologicheskih zabolevanij (po materialam peresmotra gotovy gistologicheskih preparatov $\mathrm{v}$ patologoanatomicheskom otdelenii FGBU RNIOI MZ RF). Issledovanija i praktika v medicine. 2019; 6 (1S): 148. Russian.

5. Sinelnikov IE, Baryshnikov KA, Demidov LV. Klinicheskaja diagnostika melanomy kozhi. Vestnik RONC im. N. N. Blohina RAMN. 2017; 28 (1-2): 68-73. Russian.

6. Menshhikova GV, Ermilova Al, Abramov KS, Golubev SS. Sluchai redkoj dobrokachestvennoj opuholi u rebenka. Rossijskij zhurnal kozhnyh i venericheskih boleznej. 2015; 18 (1): 15-17. Russian.

7. Junusbaeva MM, Junusbaev BB, Valiev RR, Hammatova AA, Husnutdinova YeK. Shirokoe mnogoobrazie keratinov cheloveka. Vestnik dermatologii i venerologii. 2015; (5): 42-52. Russian.

8. Sudip S, Pranaya K, Barnali C, Kisalay G. Pilomatricoma mimicking ruptured epidermal cyst in a middle aged woman. Indian Journal

of Dermatology. 2016; 61 (1): 88-90.

9. Mainak D, Indranil C. A lesson learnt: retrospection in a case of pilomatricoma mimicking as parotid neoplasm. Einstein (Sao Paulo). 2016; 14 (1): 104-5.

10. Kaprin AD, Starinskij VV, Petrova GV. Zlokachestvennye novoobrazovanija $\vee$ Rossii $\vee 2014$ godu (zabolevaemost' smertnost'). M.: MNIOI im. P. A. Gercena - filial FGBU «NMIRC» Minzdrava Rossii; 2016; 250 s. Russian.

11. Prikaz Ministerstva zdravoohranenija i social'nogo razvitija Rossijskoj Federacii ot 18 aprelja 2012g. \# 381n Ob utverzhdenii Porjadka okazanija medicinskoj pomoshhi naseleniju po profilju «Kosmetologija». Dostupno po ssylke: https://legalacts.ru/doc/ prikaz-minzdravsotsrazvitija-rossii-ot-18042012-n-381n/.

12. Fujisawa $Y$, Inoue S, Nakamura $Y$. The Possibility of Deep Learning-Based, Computer-Aided Skin Tumor Classifiers. Front Med (Lausanne). 2019; 27 (6): 191.

13. Haenssle HA, Fink C, Schneiderbauer R, Toberer F, Buhl T, Blum A, et al. Man against machine: diagnostic performance of a deep learning convolutional neural network for dermoscopic melanoma recognition in comparison to 58 dermatologists. Annals of Oncology. 2018; (0): 1-7.

14. McGee JS, Suchter MF, Milgraum SS. Multiple Familial Trichoepithelioma Successfully Treated with $\mathrm{CO}_{2}$-Laser and Imiquimod. Skinmed. 2016; Dec 1; 14 (6): 467-8.

15. Cho HJ, Lee W, Jeon MK, Park JO, Yang EJ. Staged Mosaic Punching Excision of a Kissing Nevus on the Eyelid. Aesthetic Plast Surg. 2019; Jun; 43 (3): 652-7. 


\section{Литература}

1. Кубанов А. А., Сысоева Т.А., Галлямова Ю. А., Бишарова А. С., Мерцалова И. Б. Алгоритм обследования пациентов с новообразованиями кожи. Лечащий врач. 2018; (3): 83-8.

2. Малишевская Н. П., Соколова А. В. Современные методы неинвазивной диагностики меланомы кожи. Вестник дерматологии и венерологии. 2014; (4): 46-53.

3. Rey-Barroso L, Burgos-Fernández FJ, Delpueyo X, Ares M, Royo S, Malvehy, J, et al. Visible and Extended Near-Infrared Multispectral Imaging for Skin Cancer Diagnosis Sensors. 2018; 18 (5): 1441

4. Кит О. И., Фоменко Ю. А., Карнаухов Н. С., Лаптева Т. О. Частота расхождения диагноза в прижизненной патологоанатомической диагностике онкологических заболеваний (по материалам пересмотра готовых гистологических препаратов в патологоанатомическом отделении ФГБУ РНИОИ МЗ РФ). Исследования и практика в медицине. 2019; 6 (1S): 148.

5. Синельников И. Е., Барышников К. А., Демидов Л. В. Клиническая диагностика меланомы кожи. Вестник РОНЦ им. Н. Н. Блохина РАМН. 2017; 28 (1-2): 68-73.

6. Меньщикова Г. В., Ермилова А. И., Абрамов К. С., Голубев С. С. Случаи редкой доброкачественной опухоли у ребенка. Российский журнал кожных и венерических болезней. 2015; 18 (1): 15-17.

7. Юнусбаева М. М., Юнусбаев Б. Б., Валиев Р. Р., Хамматова А. А., Хуснутдинова Э. К. Широкое многообразие кератинов человека. Вестник дерматологии и венерологии. 2015; (5): $42-52$

8. Sudip S, Pranaya K, Barnali C, Kisalay G. Pilomatricoma mimicking ruptured epidermal cyst in a middle aged woman. Indian Journal of Dermatology. 2016; 61 (1): 88-90.

9. Mainak D, Indranil C. A lesson learnt: retrospection in a case of pilomatricoma mimicking as parotid neoplasm. Einstein (Sao Paulo). 2016; 14 (1): 104-5.

10. КапринА. Д., Старинский В. В., ПетроваГ. В. Злокачественные новообразования в России в 2014 году (заболеваемость и смертность). М.: МНИОИ им. П. А. Герцена - филиал ФГБУ «НМИРЦ» Минздрава России; 2016; 250 с.

11. Приказ Министерства здравоохранения и социального развития Российской Федерации от 18 апреля 2012 г. № 381н Об утверждении Порядка оказания медицинской помощи населению по профилю «Косметология». Доступно по ссылке: https://legalacts.ru/doc/prikaz-minzdravsotsrazvitija-rossii-ot18042012-n-381n/.

12. Fujisawa $Y$, Inoue S, Nakamura $Y$. The Possibility of Deep Learning-Based, Computer-Aided Skin Tumor Classifiers. Front Med (Lausanne). 2019; 27 (6): 191.

13. Haenssle HA, Fink C, Schneiderbauer R, Toberer F, Buhl T, Blum $A$, et al. Man against machine: diagnostic performance of a deep learning convolutional neural network for dermoscopic melanoma recognition in comparison to 58 dermatologists. Annals of Oncology. 2018; (0): 1-7.

14. McGee JS, Suchter MF, Milgraum SS. Multiple Familial Trichoepithelioma Successfully Treated with $\mathrm{CO}_{2}$-Laser and Imiquimod. Skinmed. 2016; Dec 1; 14 (6): 467-8.

15. Cho HJ, Lee W, Jeon MK, Park JO, Yang EJ. Staged Mosaic Punching Excision of a Kissing Nevus on the Eyelid. Aesthetic Plast Surg. 2019; Jun; 43 (3): 652-7. 